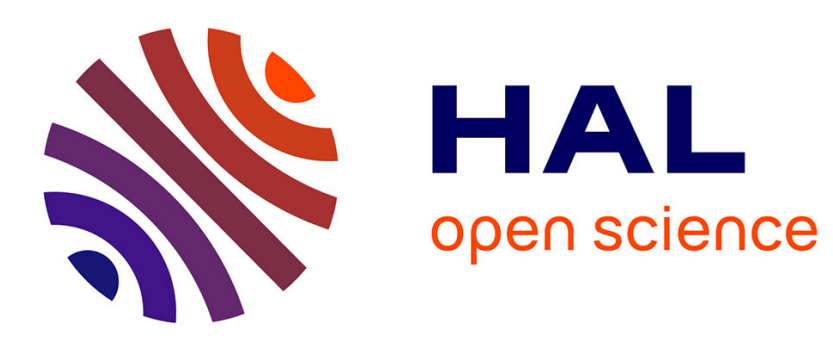

\title{
Electroactive 1,5-benzodiazepines bearing either a tetrathiafulvalene or a ferrocene moiety
}

Racheddine Kaoua, Bellara Nedjar-Kolli, Thierry Roisnel, Yann Le Gal, Dominique Lorcy

\section{- To cite this version:}

Racheddine Kaoua, Bellara Nedjar-Kolli, Thierry Roisnel, Yann Le Gal, Dominique Lorcy. Electroactive 1,5-benzodiazepines bearing either a tetrathiafulvalene or a ferrocene moiety. Tetrahedron, 2013, 69 (23), pp.4636-4640. 10.1016/j.tet.2013.04.005 . hal-00914420

\author{
HAL Id: hal-00914420 \\ https://hal.science/hal-00914420
}

Submitted on 5 Dec 2013

HAL is a multi-disciplinary open access archive for the deposit and dissemination of scientific research documents, whether they are published or not. The documents may come from teaching and research institutions in France or abroad, or from public or private research centers.
L'archive ouverte pluridisciplinaire HAL, est destinée au dépôt et à la diffusion de documents scientifiques de niveau recherche, publiés ou non, émanant des établissements d'enseignement et de recherche français ou étrangers, des laboratoires publics ou privés. 


\section{Electroactive 1,5-benzodiazepines bearing either a tetrathiafulvalene or a ferrocene moiety}

Rachedine Kaoua, ${ }^{\mathrm{a}, \mathrm{b}, \mathrm{c}}$ Bellara Nedjar-Kolli, ${ }^{\mathrm{b}^{*}}$ Thierry Roisnel, ${ }^{\mathrm{a}}$ Yann Le Gal, ${ }^{\mathrm{a}}$ Dominique Lorcy ${ }^{\mathrm{a}^{*}}$ a SCR, UMR 6226 CNRS-Université de Rennes 1, Campus de Beaulieu, Bât 10A, 35042 Rennes cedex, France.

b Laboratoire de chimie organique USTHB, 16111 Alger, Algérie. c Institut des Sciences Université Mohamed Akli Ouelhadj Bouira (UMAOB), 10000 Bouira, Algérie.
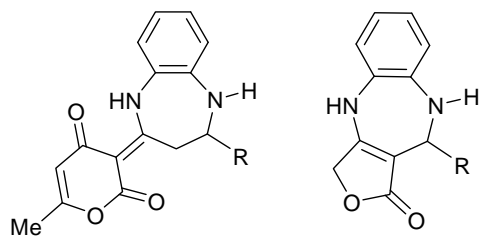

$\mathrm{R}=\mathrm{Me}_{3} \mathrm{TTF}, \mathrm{FC}$ 


\title{
Electroactive 1,5-benzodiazepines bearing either a tetrathiafulvalene or a ferrocene moiety
}

Rachedine Kaoua, ${ }^{\mathrm{a}, \mathrm{b}, \mathrm{c}}$ Bellara Nedjar-Kolli, ${ }^{\mathrm{b} *}$ Thierry Roisnel, ${ }^{\mathrm{a}}$ Yann Le Gal, ${ }^{\mathrm{a}}$ Dominique $\operatorname{Lorcy}^{\mathrm{a}^{*}}$

a Sciences Chimiques de Rennes (SCR), UMR 6226 CNRS-Université de Rennes 1, Campus de Beaulieu, Bât 10A, 35042 Rennes cedex, France. Fax : (+33)-2-23-23-67-38 E-mail : dominique.lorcy@univ-rennes1.fr

b Laboratoire de chimie organique Université des Sciences et de la Technologie "Houari Boumédienne"(USTHB), 16111 Alger, Algérie.

c Institut des Sciences Université Mohamed Akli Ouelhadj Bouira (UMAOB), 10000 Bouira, Algérie.

\begin{abstract}
The synthesis of a series of electroactive 1,5-benzodiazepines bearing either a ferrocene or tetrathiafulvalene core, acting as the electroactive moiety, is reported. The electron donating ability of these redox active 1,5-benzodiazepines is described together with their molecular structures, investigated by X-ray diffraction studies.
\end{abstract}

Keywords: dehydroacetic acid, tetrathiafulvalene, dihydropyrone, ferrocene, 1,5benzodiazepine.

\section{Introduction}


Benzodiazepines, an important class of N-heterocyclic compounds, exhibit a wide range of biological and pharmacological activities which have contributed to their use as active ingredient in numerous drugs. ${ }^{1}$ Various structures of benzodiazepines have been described and the 1,5-benzodiazepine scaffold exerts similar biological activity to that of their well known 1,4-isomers. ${ }^{2}$ Among the various analytical methods which have been used to detect these drugs or their metabolites into biological fluids the electrochemical detection is worth mentioning. This method mainly relies on the reduction of the azomethine bond of the diazepine ring. ${ }^{3,4}$ However this imine bond is reduced at quite high potential $(\mathrm{Ep}=-0.8 \mathrm{~V} v \mathrm{~s}$ $\mathrm{Ag} / \mathrm{AgCl}) .{ }^{5}$ Therefore, it would be of interest to graft on the benzodiazepine scaffold an electroactive moiety which is either easily reduced or oxidized in order to facilitate their electrochemical detection. For that purpose, two electrophores, the tetrathiafulvalene (TTF) ${ }^{6}$ and the ferrocene $(\mathrm{Fc})^{7}$ could be of interest as they both exhibit easily accessible and reversible oxidation processes. Different strategies have been studied with the aim of forming the 1,5 benzodiazepine ring. They mainly rely on the condensation reactions of $o$ phenylenediamine either with $\alpha-\beta$ unsaturated carbonyl compounds, ${ }^{8} \beta$-haloketones, ${ }^{9}$ or ketones under acid catalysis conditions. ${ }^{10}$ An efficient synthesis of 1,5-benzodiazepine bearing a pyronyl side chain in the 2 position has also been described using $o$ phenylenediamine, DHA (dehydroacetic acid) and aromatic aldehydes in the presence of catalytic amount of acid. ${ }^{11}$ Similarly, tetronic acid is known also to react with ophenylenediamine to lead to binucleophilic enaminone intermediate. Subsequent reaction of this intermediate with various electrophiles represents a versatile access to different heterocyclic structures, including benzofurodiazepine. ${ }^{12,13,14}$ Therefore the reaction of $o$ phenylenediamine with DHA or tetronic acid in the presence of different aromatic aldehydes under acid catalysis conditions leads easily to 1,5-benzodiazepine. Thus, we decided to investigate these approaches for the synthesis of electroactive benzodiazepines using either 
trimethyl-tetrathiafulvalene carboxaldehyde $\left(\mathrm{Me}_{3} \mathrm{TTFCHO}\right)$ or ferrocenecarboxaldehyde (FcCHO) as the electrophile. Herein, we report the synthesis of a series of redox-active 3,4dihydro-1,5-benzodiazepines where the electroactive lead is played by either the TTF moiety or the Fc core using as starting compounds DHA or tetronic acid. The structural and electrochemical properties are also reported.

\section{Results and discussion}

The chemical strategy we used for the synthesis of the electroactive 1,5-benzodiazepines bearing a DHA moiety and a ferrocene $(\mathrm{Fc})$ or a TTF core is outlined in Scheme 1. It relies on the reaction of o-phenylenediamine (o-PDA) with DHA in ethanol to afford the imine structure 1. Subsequent reaction of 1 with ferrocene carboxaldehyde or $\mathrm{Me}_{3} \mathrm{TTFCHO}$ in the presence of a catalytic amount of trifluoroacetic acid leads to the formation of the 1,5benzodiazepine 2 and 3 respectively. ${ }^{1} \mathrm{H}$ NMR analysis of these derivatives reveals that the $\mathrm{CH}_{2}-\mathrm{CH}$ of the seven-membered ring appears as an AMX system with a large anisochrony consistent with a 1,5-benzodiazepine structure. ${ }^{15}$ The difference in the chemical shift observed for these protons in $2\left(\mathrm{H}_{\mathrm{A}}, \delta=2.58 \mathrm{ppm} ; \mathrm{H}_{\mathrm{M}}, \delta=4.50 \mathrm{ppm} ; \mathrm{H}_{\mathrm{X}}, \delta=5.02 \mathrm{ppm}\right)$ compared to $3\left(\mathrm{H}_{\mathrm{A}}, \delta=2.85 \mathrm{ppm} ; \mathrm{H}_{\mathrm{M}}, \delta=4.17 \mathrm{ppm} ; \mathrm{H}_{\mathrm{X}}, \delta=5.35 \mathrm{ppm}\right)$, and especially to the $\mathrm{H}_{\mathrm{M}}$ one, can be infer to the different electron donor character of the TTF compared to the Fc core. 
<smiles>CC(=O)c1c(O)cc(C)oc1=O</smiles>
o-PDA DHA

1

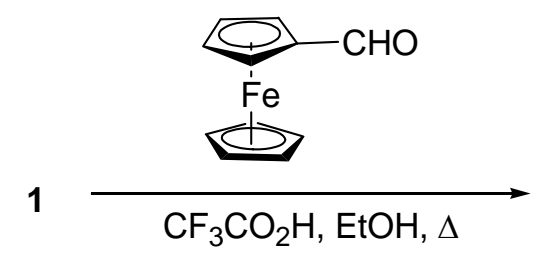<smiles>Cc1cc(O)c(C2=Nc3ccccc3NC(c3ccccc3)C2)c(=O)o1</smiles>

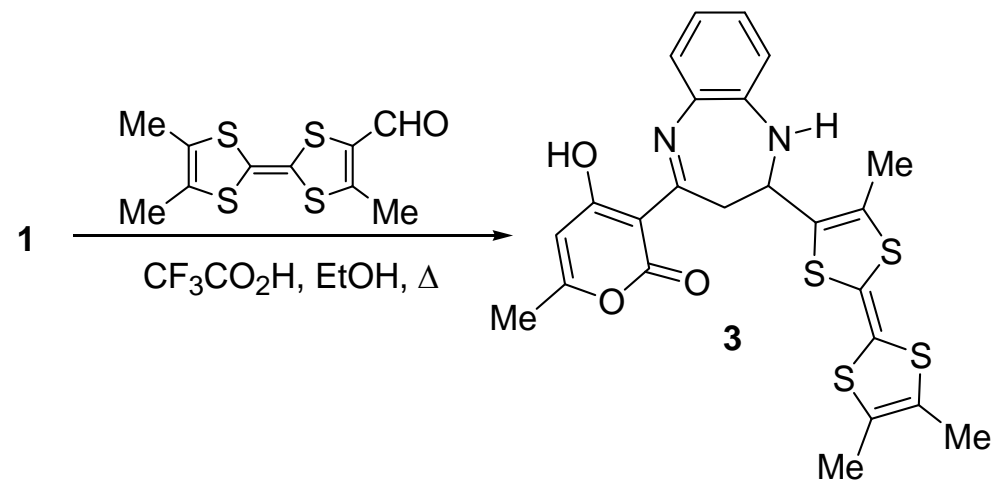

The formation of 1,5-benzodiazepine according to this strategy leads usually to a sevenmembered ring with one imine belonging to the ring. However, for the benzodiazepine bearing a DHA moiety two tautomeric forms, the enamine and the enol, can be written as depicted in Scheme 2. The chemical shift for the $\mathrm{H}$ atom involved in the hydrogen bonding between the DHA and the benzodiazepine is observed at $15.43 \mathrm{ppm}$ for $\mathbf{2}$ and $15.33 \mathrm{ppm}$ for $\mathbf{3}$ which is in accordance with either the enolic form or the enamine one (scheme 2). However, ${ }^{1} \mathrm{H}$ NMR studies carried out on analogous systems indicate the presence of the enamine structure rather than the enol one. ${ }^{15,16}$ 


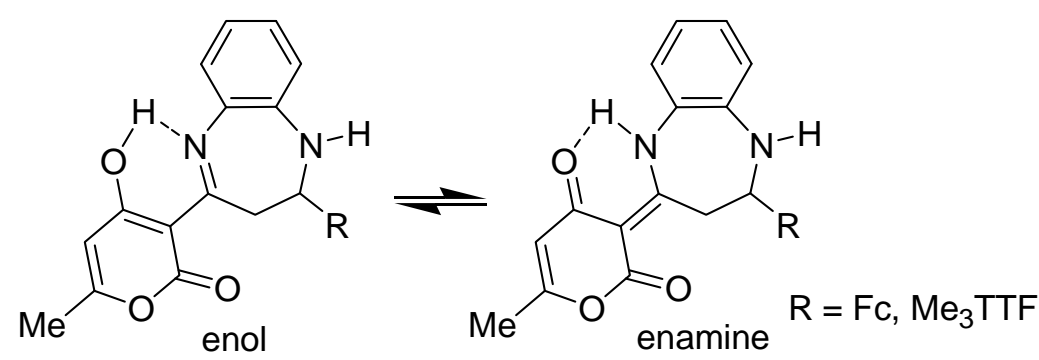

Scheme 2. Two tautomeric structures of benzodiazepines 2 and 3.

Single crystals suitable for an X-ray diffraction study were obtained for $\mathbf{2}$ by recrystallization in EtOH and for 3 by recrystallization in 1,4-dioxane. Compound 2 bearing a Fc moiety crystallizes in the monoclinic system, space group $\mathrm{P} 2{ }_{1} / \mathrm{c}$ with two independent molecules (A and B). Compound 3 crystallizes in the triclinic system, space group P-1 with one independent molecule and two solvent molecules. The molecular structures of these derivatives are represented in Figure 1 and selected bond lengths are listed in Table 1. Both molecular structures exhibit similar trends. Unambiguously, these benzodiazepines crystallize under the enamine tautomeric form (scheme 2) and as the $E$ isomer (Scheme 3) with hydrogen bonds between the $\mathrm{N}-\mathrm{H} \cdot \bullet \mathrm{O}=\mathrm{C}(1.870(38) \AA$ mole $\mathrm{A}$ and $1.792(36) \AA$ mole $\mathrm{B}$ in 2 and $1.829(34) \AA$ in 3). ${ }^{17}$<smiles>[R]C1CC(=C2C(=O)C=C(C)OC2=O)N([TlH])c2ccccc21</smiles>

E<smiles>[R]CN1C(=C2C(=O)C=C(C)OC2=O)CC([R])Nc2ccccc21</smiles>

$\boldsymbol{Z}$

Scheme 3. Two configurations of the enamine form of benzodiazepines 2 and 3.

It can be observed that the 3,4-dihydro-1,5-benzodiazepine is not planar with the folding of the seven-membered ring which adopts a boat conformation along the $\mathrm{N}^{\cdots} \mathrm{N}$ hinge. The bond lengths of the seven membered ring are of comparable values for 2 and $\mathbf{3}$ indicating that there is no influence of the nature of the electroactive moiety. The dihedral angles between the 
protons involve in the $\mathrm{AMX} \mathrm{H}^{1} \mathrm{NMR}$ pattern amounts to $177.9 \AA$ and $64.2 \AA$ for benzodiazepine 2 mole A while for 3 they amount to 173.1 and $54.9^{\circ}$ (Scheme 4). The latter dihedral angle is slightly smaller in $\mathbf{3}$ compared to the one observed in $\mathbf{2}$ probably due to the steric hindrance generated by the TTF core. Nevertheless, these dihedral angles determined in the solid state by X-ray diffraction studies are in accordance with those determined by ${ }^{1} \mathrm{H}$ NMR in solution on benzodiazepine analogues by using the coupling constant and the Karplus type equation. ${ }^{15}$ This indicates that in solution and in the solid state the seven membered ring exhibit similar conformation.

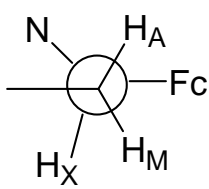

Dihedral angles in 2

Mole A

$\mathrm{H}_{\mathrm{M}}-\mathrm{C}-\mathrm{C}-\mathrm{H}_{\mathrm{X}}:$ 59.43(35) $\AA$

$\mathrm{H}_{\mathrm{A}}-\mathrm{C}-\mathrm{C}-\mathrm{H}_{\mathrm{X}}: 176.91(26) \AA$

Mole B

$\mathrm{H}_{\mathrm{M}}-\mathrm{C}-\mathrm{C}-\mathrm{H}_{\mathrm{X}}:$ 64.19(36) $\AA$

$\mathrm{H}_{\mathrm{A}}-\mathrm{C}-\mathrm{C}-\mathrm{H}_{\mathrm{X}}: 177.92(28) \AA$

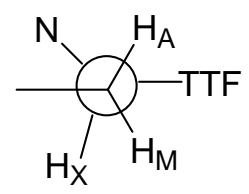

Dihedral angles in $\mathbf{3}$

$\mathrm{H}_{\mathrm{M}}-\mathrm{C}-\mathrm{C}-\mathrm{H}_{\mathrm{X}}: 54.89(28) \AA$

$\mathrm{H}_{\mathrm{A}}-\mathrm{C}-\mathrm{C}-\mathrm{H}_{\mathrm{X}}: 173.10(21) \AA$

\section{Scheme 4.}

Concerning the redox moieties, TTF and Fc, the bond lengths and the bond angles are in the usual range for such molecules and confirm that these compounds $\mathbf{2}$ and $\mathbf{3}$ are under the neutral state.

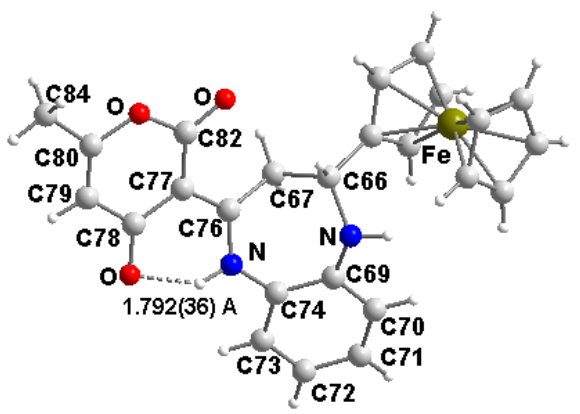




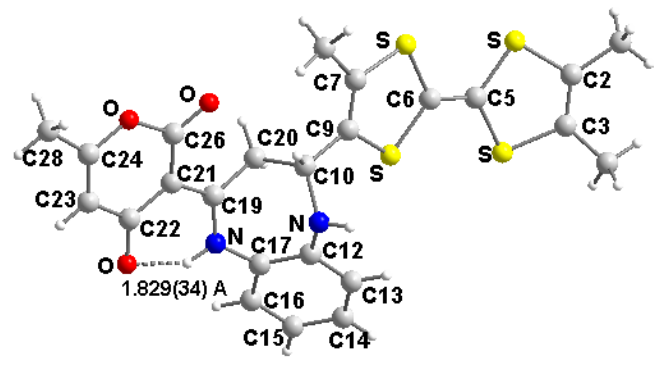

Fig. 1. Molecular structure of 1,5-benzodiazepines 2 molecule A (top) and 3 (bottom).

\section{Table 1}

Selected bond lengths $(\AA)$ of the benzodiazepine ring in 2, 3 and 5.

$\begin{array}{lllllll} & & & & & \\ & & & & & \\ \end{array}$

The other approach used to synthetize electroactive 1,5-benzodiazepines is depicted in Scheme 5 and relies on the reaction of tetronic acid with $o$-phenylenediamine. ${ }^{12-14}$ This reaction affords the 4-(2-aminophenylamino)furan-2(5H)-one 4. In refluxing EtOH, 4 in the 
presence of $\mathrm{FcCHO}$ or $\mathrm{Me}_{3} \mathrm{TTFCHO}$ and two drops of trifluoroacetic acid leads to the desired benzodiazepine 5 and 6 respectively.

Scheme 5 .<smiles>Nc1ccccc1N</smiles>
o-PDA<smiles>CCOC(C)C</smiles>
tetronic acid

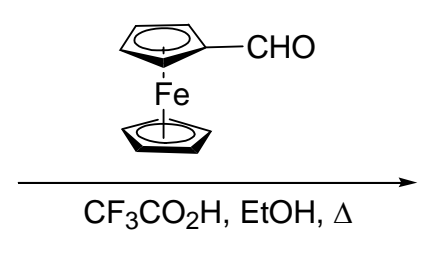

$>_{\mathrm{O}}$

4

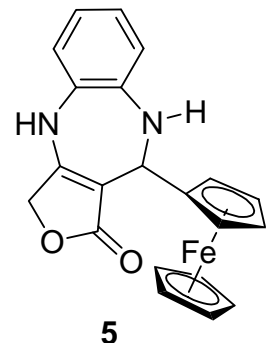

5

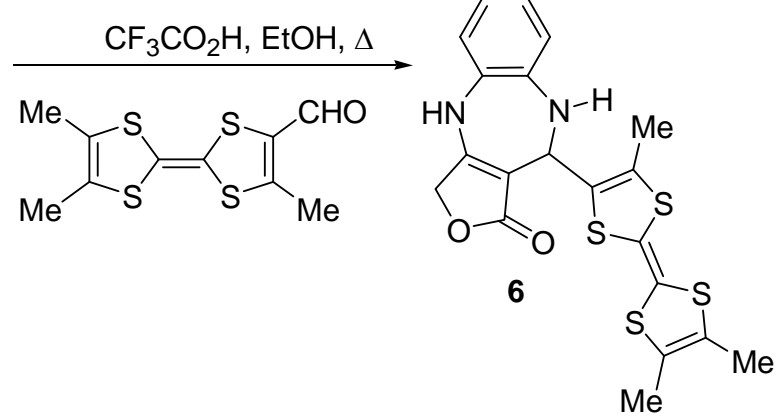

The benzodiazepine 5 crystallizes in the triclinic system, space group P-1 with two independent molecules and two molecules of EtOH. The molecular structure of $\mathbf{5}$ is depicted in Figure 2 and selected bond lengths of the diazepine ring are collected in Table 1. Within this compound the diazepine ring is less distorted compared with compounds 2 and 3 , due to the presence of the fused furanone ring. The $\mathrm{C}-\mathrm{N}$ bond lengths (Table 1), within this ring are of comparable values than the one observed for $\mathbf{2}$ and 3. Both sets of data are consistent with the presence of an enamine form with an exocyclic "ene" structure for $\mathbf{2}$ and $\mathbf{3}$ and an intra "ene" diazepine ring for 5 as the $\mathrm{C}-\mathrm{N}$ (e) bond (Table 1) is smaller than the $\mathrm{C}-\mathrm{N}$ (b) bond. Intermolecular hydrogen bonds are observed between two neighboring molecules as shown in Figure 2. This intermolecular hydrogen bonds involve the same $\mathrm{N}-\mathrm{H}$ atoms of the diazepine ring either as a donor or as an acceptor of hydrogen bonds with one molecule of EtOH and the the exocyclic $\mathrm{O}$ atom of another molecule 5. 


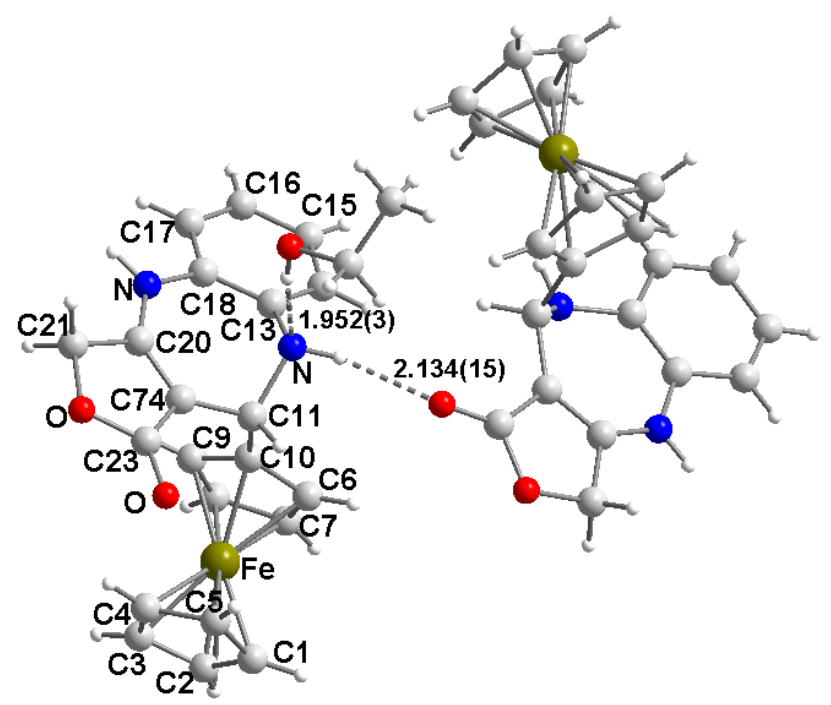

Fig. 2. Molecular structure of 1,5-benzodiazepine 5 showing the hydrogen bonds between EtOH and the $\mathrm{N}$ of 5 and between the $\mathrm{N}-\mathrm{H}$ and the $\mathrm{O}=\mathrm{C}$.

Electrochemical investigations were carried out by cyclic voltammetry and the oxidation potentials are collected in Table 1 together with the oxidation potentials of the $\mathrm{Me}_{3} \mathrm{TTFCHO}$ and FcCHO precursors. The cyclic voltammograms show that the benzodiazepines 3 and $\mathbf{6}$ containing one TTF core display two reversible monoelectronic processes corresponding to the reversible oxidation of the TTF to the cation radical species and to the dicationic one (Fig.3.). Contrariwise, the benzodiazepine substituted by a ferrocene moiety, 2 and 5 display one reversible monoelectronic oxidation process corresponding to the oxidation of the Fc to the $\mathrm{Fc}^{+}$(Fig.3.). In both families, the ferrocene/benzodiazepines and the TTF/benzodiazepines one, the presence of the DHA core induces a decrease of the overall donating ability as the first oxidation potential for $\mathbf{2}$ and $\mathbf{5}$ is anodically shifted by $120 \mathrm{mV}$ for 2 and $50 \mathrm{mV}$ for 5 compared with 3 and $\mathbf{6}$. For all these electroactive benzodiazepines, the oxidation process is observed at easily accessible oxidation potentials especially for the TTF/benzodiazepines due to the presence of the electron rich TTF core. 


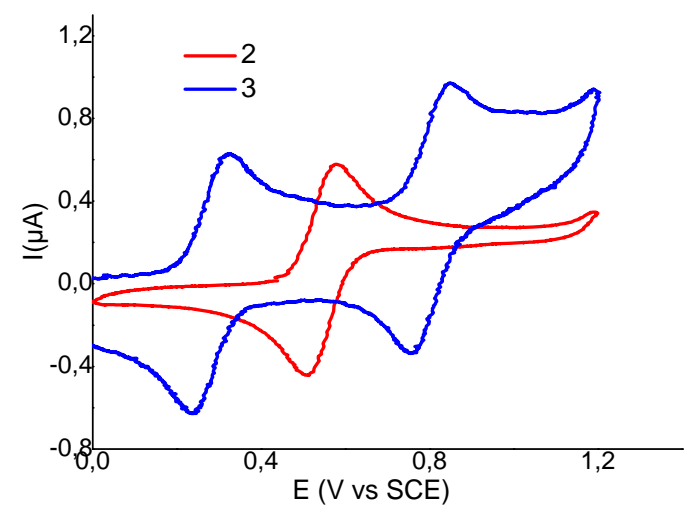

Fig. 3. Cyclic voltammograms of 2 (red) and 3 (blue) in $0.1 \mathrm{M} \mathrm{CH}_{2} \mathrm{Cl}_{2}-\left[\mathrm{NBu}_{4} \mathrm{PF}_{6}\right]$. E in $\mathrm{V} v \mathrm{~s}$ $\mathrm{SCE}, \mathrm{v}=100 \mathrm{mVs}^{-1}$.

\section{Table 2}

Oxidation potentials of the benzodiazepines 2, 3, 5 and 6, E in $\mathrm{V}$ vs. SCE, $\mathrm{CH}_{2} \mathrm{Cl}_{2}$ 0.1 M, Pt working electrode with $0.1 \mathrm{M} \mathrm{n-}$ $\mathrm{NBu}_{4} \mathrm{PF}_{6}$ scanning rate $100 \mathrm{mV} / \mathrm{s}$

\begin{tabular}{cccc}
\hline compound & $\mathrm{E}^{1}$ & $\mathrm{E}^{2}$ & $\Delta \mathrm{E} \mathrm{mV}$ \\
\hline $\mathbf{2}$ & 0.55 & - & - \\
$\mathbf{5}$ & 0.43 & - & - \\
$\mathrm{FcCHO}$ & 0.74 & - & - \\
$\mathrm{Fc}$ & 0.47 & & \\
$\mathbf{3}$ & 0.28 & 0.81 & 530 \\
$\mathbf{6}$ & 0.23 & 0.78 & 550 \\
$\mathrm{Me}_{3} \mathrm{TTFCHO}$ & 0.43 & 0.95 & 520 \\
$\mathrm{Me}_{3} \mathrm{TTF}$ & 0.27 & 0.80 & 530 \\
\hline
\end{tabular}

\section{Conclusion}

In summary, we have developed the synthesis of electroactive 1,5-benzodiazepines using a simple and compatible approach with the electroactive moiety such as the ferrocene and the 
TTF. As evidenced by X-ray diffraction studies, the diazepine rings adopt the enamine form with intramolecular hydrogen bonds between the N-H of the enamine and the carbonyl of DHA. All these benzodiazepines exhibit reversible oxidation processes at low oxidation potentials thanks to the presence of the electrophore TTF or Fc. Further investigations of the influence of the redox active moiety on the biological activity of these benzodiazepines will be investigated in due course.

\section{Experimental}

\subsection{General}

${ }^{1} \mathrm{H}$ NMR and ${ }^{13} \mathrm{C}$ NMR spectra were recorded on a Bruker Avance 300 III spectrometer with tetramethylsilane as internal reference. Chemical shifts are reported in ppm. Mass spectra and elemental analysis results were performed by the Centre de Mesures Physiques de l'Ouest, Rennes. Melting points were measured using a Kofler hot stage apparatus and are uncorrected. Cyclic voltammetry were carried out on a $10^{-3} \mathrm{M}$ solution of the compounds in dichloromethane, containing $0.1 \mathrm{M} \mathrm{nBu} 4 \mathrm{NPF}_{6}$ as supporting electrolyte. Voltammograms were recorded at $0.1 \mathrm{Vs}^{-1}$ on a platinum disk electrode $\left(\mathrm{A}=1 \mathrm{~mm}^{2}\right)$. The potentials were measured versus Saturated Calomel Electrode. $\mathrm{Me}_{3}$ TTFCHO was prepared according to published procedure. ${ }^{18}$ All the reagents were purchased and used without additional purification.

\subsection{Synthesis and characterization}

4.2.1. General procedure for the synthesis of 1,5-benzodiazepines (2-3) 
A solution of $o$-phenylenediamine $(1.08 \mathrm{~g}, 0.01 \mathrm{~mol})$ and DHA $(1.68 \mathrm{~g}, 0.01 \mathrm{~mol})$ in $50 \mathrm{~mL}$ of EtOH was stirred for $3 \mathrm{~h}$. The precipitate was filtered, washed with diethyl ether and dried. Compound 1 was obtained in $90 \%$ yield and used in the next step without further purification. To a stirred suspension of $1(0.12 \mathrm{~g}, 0.5 \mathrm{mmol})$ in $10 \mathrm{~mL}$ of EtOH was added 0.5 mmole of the aldehyde $\left(0.137 \mathrm{~g}\right.$ for $\mathrm{FcCHO}$ and $0.107 \mathrm{~g}$ for $\left.\mathrm{Me}_{3} \mathrm{TTFCHO}\right)$ and two drops of $\mathrm{CF}_{3} \mathrm{CO}_{2} \mathrm{H}$. The mixture was then refluxed for $6 \mathrm{~h}$ and the reaction was monitored by TLC. The resulting mixture was allowed to stand at room temperature and the precipitate was filtered and washed with water. The precipitate was dissolved in $30 \mathrm{~mL}$ of $\mathrm{CH}_{2} \mathrm{Cl}_{2}$ and washed with water dried over $\mathrm{MgSO}_{4}$. The solvent was evaporated and the residue was recrystallized in EtOH for 2 and in dioxane for 3.

Benzodiazepine 2 was obtained as yellow powder in $74 \%$ yield. $\mathrm{Mp}=212{ }^{\circ} \mathrm{C} ;{ }^{1} \mathrm{H}$ NMR $\left(\mathrm{CD}_{3} \mathrm{Cl}\right) \partial(\mathrm{ppm}) 2.18\left(\mathrm{~s}, 3 \mathrm{H}, \mathrm{CH}_{3}\right), 2.58\left(\mathrm{dd}, 1 \mathrm{H}, \mathrm{J}=12.4, \mathrm{~J}=11.4, \mathrm{CH}_{2}\right), 4.13(\mathrm{~s}, 1 \mathrm{H}, \mathrm{H}-\mathrm{N})$, 4.16-4.23(m, 4H, Fc), 4.28(s, 5H, Fc), 4.5(dd, 1H, J=12.4, 3.3, $\left.\mathrm{CH}_{2}\right), 5.02(\mathrm{dd}, 1 \mathrm{H}, \mathrm{J}=11.4$, 3.3, $\left.\mathrm{CH}_{2}\right), \quad 5.80(\mathrm{~s}, 1 \mathrm{H}, \mathrm{CH}=\mathrm{C}), 6.81-6.93(\mathrm{~m}, 1 \mathrm{H}, \mathrm{H}-\mathrm{Ar}), 6.94-7.07(\mathrm{~m}, 1 \mathrm{H}, \mathrm{H}-\mathrm{Ar}), 7.12-$ 7.25(m, 2H, H-Ar) 15.43(s, 1H, NH); ${ }^{13} \mathrm{C} \mathrm{NMR}\left(\mathrm{CD}_{3} \mathrm{Cl}\right) \delta 19.9$ (C84), 36.6 (C67), 64.2(Cp), 65.2 (C66), 66.3(Cp), 68.2(Cp), 68.6 (Cp), 92.7 (Cp), 96.4 (C77), 107.4 (C79), 121.6 (Ar), 121.8 (Ar), 122.4 (Ar), 126.7 (Ar), 128.4(Ar), 140.1 (C69), 163.2 (C80), 163.7 (C82), 172.9 (C76), 184.8.(C78); UV-vis $\left(\mathrm{CH}_{2} \mathrm{Cl}_{2}\right) \lambda\left(\varepsilon \mathrm{L} \cdot \mathrm{mol}^{-1} \mathrm{~cm}^{-1}\right): 238$ (29910), 322 (11360), 375 (14940) ; HRMS calcd for $\mathrm{C}_{25} \mathrm{H}_{22} \mathrm{~N}_{2} \mathrm{O}_{3} \mathrm{Fe}^{56} \mathrm{M}^{+} \cdot 454.09798$. Found 454.0977.

Benzodiazepine 3 was obtained as brown powder in $67 \%$ yield. $\mathrm{Mp}=152{ }^{\circ} \mathrm{C} ;{ }^{1} \mathrm{HNMR}$ $\left(\mathrm{CD}_{3} \mathrm{Cl}\right) \partial(\mathrm{ppm}) 1.91\left(\mathrm{~s}, 3 \mathrm{H}, \mathrm{CH}_{3}\right), 1.93\left(\mathrm{~s}, 3 \mathrm{H}, \mathrm{CH}_{3}\right), 2.15\left(\mathrm{~s}, 3 \mathrm{H}, \mathrm{CH}_{3}\right), 2.17\left(\mathrm{~s}, 3 \mathrm{H}, \mathrm{CH}_{3}\right)$, 2.84(dd, 1H, J=12.2, J=10.9, $\left.\mathrm{CH}_{2}\right), 3.88(\mathrm{~s}, 1 \mathrm{H}, \mathrm{NH}), 4.17\left(\mathrm{dd}, 1 \mathrm{H}, \mathrm{J}=12.2,3.4, \mathrm{CH}_{2}\right), 5.35(\mathrm{dd}$, $\left.1 \mathrm{H}, \mathrm{J}=10.9,3.4, \mathrm{CH}_{2}\right), 5.79(\mathrm{~s}, 1 \mathrm{H}, \mathrm{CH}=\mathrm{C}), 7.21-7.25(\mathrm{~m}, 1 \mathrm{H}, \mathrm{H}-\mathrm{Ar}), 7.02-7.10$ (m, 2H, H-Ar), 7.14-7.18 (m, 1H, H-Ar), 15.33(s, $1 \mathrm{H}, \mathrm{NH}) ;{ }^{13} \mathrm{C}$ NMR $\left(\mathrm{CD}_{3} \mathrm{Cl}\right) \delta 13.3\left(\mathrm{CH}_{3} \mathrm{TTF}\right), 13.4$ 
( $\left.\mathrm{CH}_{3} \mathrm{TTF}\right), 13.5$ ( $\left.\mathrm{CH}_{3} \mathrm{TTF}\right), 19.2$ (C28), 34.6 (C20), 62.7 (C10), 96.1 (C21), 107.1 (C23), $107.3(\mathrm{C}=\mathrm{C}$ TTF $), 121.1(\mathrm{Ar}), 121.5(\mathrm{Ar}), 122.6(\mathrm{Ar}), 122.8(\mathrm{C}=\mathrm{C}$ TTF$), 124.3(\mathrm{C}=\mathrm{C}$ TTF $)$, 125.9 (Ar), 128.3 (Ar), 132.9 (C=C TTF), 140.4 (C12), 161.9 (C24), 164.6 (C26), 171.7

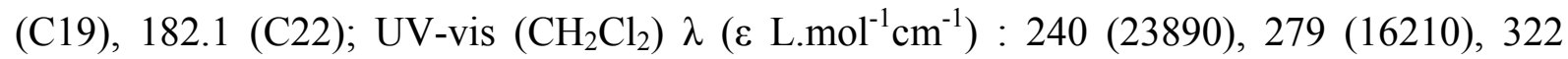
(20150), 368 (15670) ; HRMS calcd for $\mathrm{C}_{24} \mathrm{H}_{22} \mathrm{~N}_{2} \mathrm{O}_{3} \mathrm{~S}_{4} \mathrm{M}^{+} \cdot$ 514.05133. Found 514.0513; Anal calcd for $\mathrm{C}_{24} \mathrm{H}_{22} \mathrm{~N}_{2} \mathrm{O}_{3} \mathrm{~S}_{4} \mathrm{C}, 56.01 ; \mathrm{H}, 4.31 ; \mathrm{N}, 5.44 ; \mathrm{S}, 24.92$ Found: C, 55.89; H, 4.32; N, 5.36; S, 24.80.

\subsubsection{General procedure for the synthesis of 1,5-benzodiazepines (5-6)}

A solution of $o$-phenylenediamine $(1.08 \mathrm{~g}, 0.01 \mathrm{~mol})$ and tetronic acid $(1 \mathrm{~g}, 0.01 \mathrm{~mol})$ in 25 $\mathrm{mL}$ of EtOH was refluxed for $30 \mathrm{~min}$. The mixture was cooled to room temperature and the precipitate was filtered recovered by filtration. Compound 4 was recrystallized in EtOH. To a stirred suspension of $4(950 \mathrm{mg}, 0.5 \mathrm{mmol})$ in $10 \mathrm{~mL}$ of EtOH was added 0.5 mmole of the aldehyde $\left(0.137 \mathrm{~g}\right.$ for $\mathrm{FcCHO}$ and $0.107 \mathrm{~g}$ for $\left.\mathrm{Me}_{3} \mathrm{TTFCHO}\right)$ and two drops of $\mathrm{CF}_{3} \mathrm{CO}_{2} \mathrm{H}$. The mixture was then refluxed for $6 \mathrm{~h}$ and the reaction was monitored by TLC. The resulting mixture was allowed to stand at room temperature and the precipitate was filtered and washed with water. The precipitate was dissolved in $30 \mathrm{~mL}$ of $\mathrm{CH}_{2} \mathrm{Cl}_{2}$ and washed with water dried over $\mathrm{MgSO}_{4}$. The solvent was evaporated and the residue was recrystallized in $\mathrm{EtOH}$ for 5 and in DMF for 6.

Benzodiazepine 5 was obtained as yellow powder in $73 \%$ yield. $\mathrm{Mp}=248{ }^{\circ} \mathrm{C} ;{ }^{1} \mathrm{H}$ NMR $\left(\right.$ DMSO-d $\left._{6}\right) \partial$ (ppm) 3.75 (m, 1H, H-Ferr), 3.88 (m, 1H, H-Ferr), 3.96 (m, 1H, H-Ferr), 4.09 (m, 1H, H-Ferr), 4.11 (s, 5H, H-Ferr), $4.82\left(\mathrm{~d}, 2 \mathrm{H}, \mathrm{J}=4.9 \mathrm{~Hz}, \mathrm{CH}_{2}\right), 4.88(\mathrm{~d}, \mathrm{~J}=4.5 \mathrm{~Hz}, 1 \mathrm{H}$, CH), $5.78(\mathrm{~d}, \mathrm{~J}=4.9 \mathrm{~Hz}, 1 \mathrm{H}, \mathrm{NH}), 6.62-6.72(\mathrm{~m}, 3 \mathrm{H}, \mathrm{H}-\mathrm{Ar}), 6.78-6.82(\mathrm{~m}, 1 \mathrm{H}, \mathrm{H}-\mathrm{Ar}), 9.70(\mathrm{~s}$, 1H, NH) ${ }^{13} \mathrm{C}$ NMR (DMSO-d 6 ) $\delta 52.6(\mathrm{CH}$, diazepine), 65.7 (Cp), $66.0(\mathrm{Cp}), 66.1(\mathrm{Cp}), 66.6$ $(\mathrm{Cp}), 67.4\left(\mathrm{CH}_{2}\right), 68.4(\mathrm{Cp}), 93.2(\mathrm{Cp}), 98.3(\mathrm{C}=\mathrm{C}$, diazepine $), 119.3(\mathrm{C}=\mathrm{C}$, diazepine $), 120.4$ 
(Ar), 122.5 (Ar), $122.7(\mathrm{Ar}), 130.9$ (Ar), $138.2(\mathrm{Ar}), 158.6(\mathrm{Ar}), 172.9\left(\mathrm{CO}_{2}\right)$; UV-vis $\left(\mathrm{CH}_{2} \mathrm{Cl}_{2}\right) \lambda\left(\varepsilon \mathrm{L} \mathrm{mol}^{-1} \mathrm{~cm}^{-1}\right): 243$ (21300), 307 (7710), 451 (750); HRMS calcd for $\mathrm{C}_{21} \mathrm{H}_{18} \mathrm{~N}_{2} \mathrm{O}_{2} \mathrm{Fe}^{56} \mathrm{M}^{+} \cdot 386.07177$. Found 386.0729.

Benzodiazepine 6 was obtained as brown powder in $63 \%$ yield. $\mathrm{Mp}=278{ }^{\circ} \mathrm{C} ;{ }^{1} \mathrm{H}$ NMR $\left(\mathrm{DMSO}_{6}\right) \partial(\mathrm{ppm}) 1.84\left(\mathrm{~s}, 3 \mathrm{H}, \mathrm{CH}_{3}\right), 1.87\left(\mathrm{~s}, 3 \mathrm{H}, \mathrm{CH}_{3}\right), 2.15\left(\mathrm{~s}, 3 \mathrm{H}, \mathrm{CH}_{3}\right), 4.84(\mathrm{~s}, 2 \mathrm{H}$, $\mathrm{CH}_{2}$ ), 4.98 (d, 1H, J=3.8 Hz, CH), 5.98 (d, 1H, J=3.7 Hz, NH), 6.82-6.94 (m, 4H, H-Ar), 9.91 (s, 1H, NH) ; ${ }^{13} \mathrm{C}$ NMR (DMSO-d 6$) 13.3\left(\mathrm{CH}_{3} \mathrm{TTF}\right), 13.4\left(\mathrm{CH}_{3} \mathrm{TTF}\right), 14.1\left(\mathrm{CH}_{3} \mathrm{TTF}\right), 51.9$ $\left(\mathrm{CH}\right.$, diazepine), $66.1\left(\mathrm{CH}_{2}\right), 95.7(\mathrm{C}=\mathrm{C}$, diazepine $), 113.7(\mathrm{C}=\mathrm{C}$ TTF $), 119.8(\mathrm{C}=\mathrm{C}$, diazepine), 121.1 (Ar), 122.7 (Ar), 123.4 (Ar), 125.3 (C=C TTF), 130.9 (Ar), 136.7 (Ar),

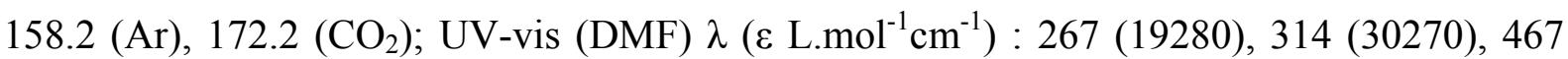
(530); HRMS calcd for $\mathrm{C}_{20} \mathrm{H}_{18} \mathrm{~N}_{2} \mathrm{O}_{2} \mathrm{~S}_{4} \mathrm{M}^{+}$. 446.02512 Found . 446.0252. Anal calcd for $\mathrm{C}_{20} \mathrm{H}_{18} \mathrm{~N}_{2} \mathrm{O}_{2} \mathrm{~S}_{4} \mathrm{C}, 53.78 ; \mathrm{H}, 4.06 ; \mathrm{N}, 6.27 ; \mathrm{S}, 28.72$. Found: C, 53.32; H, 4.09; N, 6.10; $\mathrm{S}$, 28.81 .

\subsection{Crystallography}

Single-crystal diffraction data were collected on APEX II Bruker AXS diffractometer, Mo-K $\alpha$ radiation $(\lambda=0.71073 \AA$ ), for compounds 2, 3 and 5 (Centre de Diffractométrie X, Université de Rennes, France). The structures were solved by direct methods using the SIR97 program ${ }^{19}$, and then refined with full-matrix least-square methods based on $\mathrm{F}^{2}\left(\mathrm{SHELX}_{-97}{ }^{20}\right.$ with the aid of the WINGX program. ${ }^{21}$ All non-hydrogen atoms were refined with anisotropic atomic displacement parameters. Except nitrogen linked hydrogen atoms that were introduced in the structural model through Fourier difference maps analysis, $\mathrm{H}$ atoms were finally included in their calculated positions. 
Crystal data for $2\left(2\left(\mathrm{C}_{25} \mathrm{H}_{22} \mathrm{FeN}_{2} \mathrm{O}_{3}\right)\right) ; \mathrm{M}=908.59$. $\mathrm{T}=150(2) \mathrm{K}$; monoclinic $P 2_{1} / c$, a = 6.2447(11), $\mathrm{b}=27.047(5), \mathrm{c}=23.789(4) \AA, \beta=95.263(9)^{\circ}, V=4001.0(12) \AA^{3}, Z=4, d=$ $1.508 \mathrm{~g} . \mathrm{cm}^{-3}, \mu=0.785 \mathrm{~mm}^{-1}$. A final refinement on $F^{2}$ with 9103 unique intensities and 573 parameters converged at $\omega R\left(F^{2}\right)=0.0964(R(F)=0.0492)$ for 5215 observed reflections with $I>2 \sigma(I)$.

Crystal data for $3\left(\mathrm{C}_{24} \mathrm{H}_{22} \mathrm{~N}_{2} \mathrm{O}_{3} \mathrm{~S}_{4}, 1.5\left(\mathrm{C}_{4} \mathrm{H}_{8} \mathrm{O}_{2}\right)\right) ; \mathrm{M}=646.83 . \mathrm{T}=150(2) \mathrm{K}$; triclinic $P-1$, $\mathrm{a}=7.6361(3), \mathrm{b}=11.8253(4), \mathrm{c}=17.0490(6) \AA, \alpha=96.626(2), \beta=92.349(2), \gamma=99.234(2)$ ${ }^{\circ}, V=1506.63(9) \AA^{3} . Z=2, d=1.426 \mathrm{~g} . \mathrm{cm}^{-3}, \mu=0.362 \mathrm{~mm}^{-1}$. A final refinement on $F^{2}$ with 6744 unique intensities and 389 parameters converged at $\omega R\left(F^{2}\right)=0.1188(R(F)=0.0526)$ for 4826 observed reflections with $I>2 \sigma(I)$.

Crystal data for $5\left(\mathrm{C}_{21} \mathrm{H}_{18} \mathrm{Fe}_{1} \mathrm{~N}_{2} \mathrm{O}_{2}\right) ; \mathrm{M}=864.58 . \mathrm{T}=150(2) \mathrm{K}$; triclinic $P-1, \mathrm{a}=10.9619(7)$, $\mathrm{b}=13.7303(9), \mathrm{c}=14.9665(10) \AA, \alpha=83.262(3), \beta=73.607(3), \gamma=66.771(2) \circ, V=$ 1985.8(2) $\AA^{3}, Z=2, d=1.446$ g.cm $\mathrm{cm}^{-3}, \mu=0.787 \mathrm{~mm}^{-1}$. A final refinement on $F^{2}$ with 8853 unique intensities and 533 parameters converged at $\omega R\left(F^{2}\right)=0.0802(R(F)=0.0358)$ for 7242 observed reflections with $I>2 \sigma(I)$.

\section{Supplementary material}

Crystallographic data for structural analysis have been deposited with the Cambridge Crystallographic Data Centre, CCDC n $922159-922161$ for compounds 2, 3 and 5. Copies of this information may be obtained free of charge from The CCDC, 12 Union road, Cambridge CB2 1EZ, UK (Fax: +44-1223-336033; e-mail: deposit@ccdc.cam.ac.uk or www: http://www.ccdc.cam.ac.uk). 
${ }^{1}$ (a) Schutz, H. Benzodiazepines; Springer: Heidelberg, 1982; (b) Landquist, J. K. In Comprehensive Heterocyclic Chemistry, Vol. 1; Katritzky, A. R.; Rees, C. W. Eds.; Pergamon: Oxford, 1984; pp 166-170; (c) Smalley, R. K. In Comprehensive Organic Chemistry; Barton, D.; Ollis, W. D., Eds.; Pergamon: Oxford, 1979; Vol. 4, p 600; (e) Randall, L. O.; Kappel, B. In Benzodiazepines; Garattini, S.; Mussini, E.; Randall, L. O.; Eds.; Raven Press: New York, 1973; p 27.

2 (a) Qian, J. Liu, Y. Cui, J. Xu, Z. J. Org. Chem. 2012, 77, 4484-4490; (b) Neochoritis, C. G. Tsoleridis, C. A.; Stephanidou-Stephanatou, J.; Kontogiorgis, C. A.; Hadjipavlou-Litina D. J. J. Med. Chem. 2010, 53, 8409-8420

${ }^{3}$ Wilhelm, M.; Battista, H.-J.; Obendorf D. J. Chromatogr. A, 2000, 897, 215-225

${ }^{4}$ El-Hefnawey, G.B.; El-Hallag, I.S.; Ghoneim, E.M.; Ghoneim, M.M. J. Pharm. Biomed., 2004, 34, 75-86

${ }^{5}$ Doherty, B.; O’Donnell, F.; Smyth, W. F.; Leslie, J. C.; Ramachandran, V. N.; Boyd, N. S.; Hack, C. J.; O’Kane, E.; McClean, S. Talanta, 2007, 72, 755-761.

${ }^{6}$ Special issue on "Molecular conductors" Batail, P. Ed. Chem. Rev. 2004, 104, 4887-5781.

${ }^{7}$ van Staveren, D. R.; Metzler-Nolte, N. Chem. Rev. 2004, 104, 5931-5985.

${ }^{8}$ (a) Balakrishna, M. S.; Kaboudin, B. Tetrahedron Lett. 2001, 42, 1127-1129. (b) Stahlofen, P.; Ried, W. Chem. Ber. 1957, 90, 815-816. (c) Pozarentzi, M.; Stephanidou-Stephanatou, J.; Tsoleridis, C. A. Tetrahedron Lett. 2002, 43, 1755-1758. (d) Nedjar-Kolli, B.; Hamdi, M.; Pecher, J., Synth. Commun. 1990, 20(11), 1579-1587.

${ }^{9}$ (a) Aversa, M. C.; Ferlazzo, A.; Gionnetto, P.; Kohnke, F. H. Synthesis 1986, 230-231; (b) Essaber, M.; Baouid, A.; Hasnaoui, A.; Benharref, A.; Lavergne, J. P. Synth. Commun. 1998, 28, 4097-4105; (c) Xu, J. X.; Wu, H. T.; Jin, S. Chin. J. Chem. 1999, 17, 84-91; (d) Zhang, X. Y.; Xu, J. X.; Jin, S. Chin. J. Chem. 1999, 17, 404-410; (e) Reddy, K. V. V.; Rao, P. S.; 
Ashok, D. Synth. Commun. 2000, 30, 1825-1836; (f) El-Sayed, A. M.; Abdel-Ghany, H.; ElSaghier, A. M. M. Synth. Commun. 1999, 29, 3561-3572; (g) Ried, W.; Torinus, E. Chem. Ber. 1959, 92, 2902-2916; (h) Herbert, J. A. L.; Suschitzky, H. J. Chem. Soc., Perkin Trans. 1 1974, 2657-2661; (i) Morales, H. R.; Bulbarela, A.; Contreras, R. Heterocycles 1986, 24, 135-139; (j) Jung, D. I.; Choi, T. W.; Kim, Y. Y.; Kim, I. S.; Park, Y. M.; Lee, Y. G.; Jung, D. H. Synth. Commun. 1999, 29, 1941-1951; (k) Papori, G.; Babulal, D. Synth. Commun. 2010, 40, 1685-1693; (1) Chun-Wei, K.; Chun-Chao, W.; Veerababurao, K.; Ching-Fa, Y. Molecules 2008, 13, 2313-2325; (m) Xiang- Qiang, P.; Jian-Ping, Z.; Zhi-Hao, H.; Wei, Z. Tetrahedron Lett. 2008, 49, 5302-5308; (n) Erker, T. Liebigs Ann. Chem. 1989, 6, 601-604.

${ }^{10}$ Bandgar, B.P.; Patil, A.V.; Chavan, O.S. J. Mol. Catal. A, 2006, 256, 99-105 and references cited therein.

${ }^{11}$ (a) Kaoua, R.; Bennamane, N.; Bakhta, S.; Benadji,S.; Rabia, C. ; Nedjar-Kolli, B. Molecules, 2011, 16(1), 92-99; (b) Fodili, M.; Amari, M.; Kolli, B.; Robert, A.; Baudy-Floc'h, M.; Le grel P. Synthesis, 1999, 811-814.

${ }^{12}$ Shuliang, W.; Chuang, C.; Feng, G.; Feiyue, W.; Bo, J.; Jianfeng, Z.; Shujiang, T. Chin. J. Chem. 2011, 29, 2101-2108.

${ }^{13}$ Cheng, C.; Jiang, b.; Tu, S.-J.; Li, G. Green Chem. 2011, 13, 2107-2115.

${ }^{14}$ Hammal, L. Bentarzi, Y. Kolli-Nedjar, B.; Hoffmann, P., Heterocyclic Commun, 2009, 15(3), 209-216. (b)Amari, M.; Fodili, M.; Nedjar-Kolli, B.; Hoffmann, P.; Périé, J.J., J. Heterocyclic Chem, 2002, 39, 811-816.

${ }^{15}$ Claramunt, R. M.; Sanz, D.; Aggarwal, S.; Kumar, A.; Prakash, O.; Singh, S. P.; Elguero, J. Arkivoc, 2006, xiv, 35-45.

${ }^{16}$ Tjiou, E. M. Lhoussaine, E. G. Virieux, D. Fruchier A. Magn. Reson. Chem. 2005, 43, $557-562$

${ }^{17}$ Steiner, T. Angew. Chem. Int. Ed. 2002, 41, 48-76 
18 . Moore, A. J.; Bryce, M. R.; Batsanov, A. S.; Cole J. C.; Howard, J. A. K. Synthesis 1995, 675-682.

${ }^{19}$ Altomare, A.; Burla, M. C.; Camalli, M.; Cascarano, G.; Giacovazzo, C.; Guagliardi, A.; Moliterni, A. G. G.; Polidori, G.; Spagna, R. J. Appl. Cryst. 1999, 32, 115-119.

${ }^{20}$ Sheldrick G.M., Acta Cryst. 2008, A64, 112-122.

${ }^{21}$ Farrugia, L. J. J. Appl. Cryst., 1999, 32, 837-838. 